\title{
De Tijdelijke wet COVID-19 Justitie en Veiligheid
}

\author{
Meer mogelijkheden voor rechtspersonen tot het gebruik van elektronische \\ communicatiemiddelen en het uitstellen van termijnen
}

\author{
Mr. S. Rietveld en mr. L.E. Stroeve*
}

\begin{abstract}
In deze bijdrage bespreken de auteurs de op 24 april 2020 in werking getreden Tijdelijke wet COVID-19 Justitie en Veiligheid. Deze wet geeft verschillende voorzieningen voor vergaderingen van bestuur en raad van commissarissen, algemene vergaderingen, ledenvergaderingen en verslaglegging door tijdelijke afwijkingen van en aanvullingen op Boek 2 $B W$ toe te staan.
\end{abstract}

\section{Inleiding}

Het Nederland van twee maanden geleden is niet het Nederland van nu. Vanwege de uitbraak van het coronavirus en de bestrijding daarvan heeft het Nederlandse kabinet diverse overheidsmaatregelen opgelegd om de volksgezondheid en de economie te beschermen. ${ }^{1}$ Zo wordt een beroep gedaan op Nederlanders om gepaste afstand van elkaar (circa anderhalve meter) te houden en zijn bijeenkomsten met meer dan 100 personen in heel Nederland niet langer mogelijk. Deze overheidsmaatregelen zijn vooralsnog van toepassing tot en met 19 mei 2020. De kans bestaat echter dat het kabinet besluit om deze maatregelen - al dan niet in afgezwakte vorm - te verlengen.

Naast de directe bestrijding van het coronavirus is het van belang dat de samenleving als geheel zo veel als mogelijk normaal blijft functioneren. De bij rechtspersonen betrokkenen zien zich binnen dit kader genoodzaakt voortdurend keuzes te maken, rekening houdend met de risico's voor de volksge-

Mr. S. Rietveld is Staff Associate bij Stibbe te Amsterdam. Mr. L.E. Stroeve is kandidaat-notaris bij Stibbe te Amsterdam.

1. Zie hierover bijv. het persbericht van 21 april 2020 (www.rijksoverheid.nl/actueel/nieuws/2020/04/21/maatregelencorona-verlengd) en vragen en antwoorden over de Nederlandse aanpak en veranderingen na 28 april 2020 (www.rijksoverheid.nl/onderwerpen/ coronavirus-covid-19/openbaar-en-dagelijks-leven/aanpak/

veranderingen-na-28-april-2020), en eerder 23 maart 2020 (www.rijksoverheid.nl/actueel/nieuws/2020/03/23/aangescherptemaatregelen-om-het-coronavirus-onder-controle-te-krijgen), de nadere uitwerking en precisering daarvan op 24 maart 2020 (www.rijksoverheid.nl/actueel/nieuws/2020/03/24/aanvullendemaatregelen-23-maart) en veelgestelde vragen en antwoorden (www.rijksoverheid.nl/onderwerpen/coronavirus-covid-19/veelgesteldevragen-per-onderwerp/aanpak-in-nederland). zondheid, de overheidsmaatregelen en mogelijk intern (corona)beleid. Tegelijkertijd worden zij belemmerd in het maken van deze keuzes, daar waar wet of statuten niet die mogelijkheden bieden die in deze crisissituatie nodig zijn. Voor de voortgang van de bedrijfsvoering van rechtspersonen is het van belang dat overleg en besluitvorming mogelijk blijven, ook als fysiek samenkomen moeilijk of onmogelijk is. Uitgangspunt van de wet is echter nog steeds dat vergaderingen in fysieke vorm moeten plaatsvinden.

Bestuurders en toezichthouders zouden de mogelijkheid moeten hebben om met behulp van elektronische communicatiemiddelen te overleggen en te besluiten, maar hebben daar soms geen statutaire regeling voor getroffen, waardoor zij tegen beperkingen aanlopen. Algemene vergaderingen (AVA's) of ledenvergaderingen van rechtspersonen waarbij normaliter veel mensen fysiek bij elkaar komen, kunnen als gevolg van de coronamaatregelen niet meer (of in ieder geval niet meer op dezelfde wijze) plaatsvinden. Hierdoor kunnen bepaalde besluiten, zoals vaststelling van de jaarrekening, de uitkering van dividend en de benoeming van bestuurders en toezichthouders, niet meer worden genomen of zijn deze besluiten, indien wel genomen, mogelijk aantastbaar.

De problemen zijn met name zichtbaar bij de AVA's van beursvennootschappen, waar naast aandeelhouders ook vaak het voltallige bestuur, de raad van commissarissen, de accountant, de notaris, eventuele pers, eventuele tolken en mensen van de organisatie en techniek aanwezig zijn. Bij BV's en NV's met slechts één of een beperkt aantal aandeelhouders en bestuurders speelt deze problematiek minder. Hier zal in de praktijk besluitvorming zo veel mogelijk schriftelijk worden vastgelegd, en zal communicatie zo veel mogelijk via elektronische communicatiemiddelen (per e-mail, telefonisch, enzovoort) plaatsvinden.

De maatregelen die met name beursvennootschappen in het kader van corona (moeten) nemen, liggen onder een vergrootglas aangezien de coronacrisis samenvalt met het jaarlijkse algemene vergaderingenseizoen (AVA-seizoen). $\mathrm{Nu}$ de wet 
bepaalt dat de jaarlijkse AVA wordt gehouden binnen zes maanden na afloop van het boekjaar van de vennootschap (art. 2:108 lid 2 BW) op een plaats in Nederland zoals bij de statuten vermeld (art. 2:116 lid $1 \mathrm{BW}$ ), en het door de coronacrisis ingewikkelder is geworden om fysieke vergaderingen te houden, ziet het bestuur van beursvennootschappen zich geconfronteerd met diverse vraagstukken als: zijn er mogelijkheden om aandeelhouders op afstand te laten stemmen, kunnen aandeelhouders worden geweigerd om naar de AVA te komen, kan er volledig virtueel worden vergaderd of moet de AVA juist worden uitgesteld, en welke gevolgen heeft dit voor de verschillende agendapunten, en maakt het hierbij nog verschil of de AVA reeds is opgeroepen of niet? Soortgelijke vraagstukken spelen overigens ook bij grote coöperaties, die hun jaarlijkse ledenvergadering ook in dit seizoen dienen te houden. Kortom, het coronavirus zorgt voor de nodig opschudding en ook het bedrijfsleven wordt hierdoor flink geraakt.

Daar waar bestaande wetgeving geen of te weinig ruimte biedt om praktische problemen ten gevolge van de coronacrisis op te lossen, zijn tijdelijk aanvullende wettelijke voorzieningen of aanpassingen nodig. Een viertal belangenorganisaties (VNONCW en de VEUO namens het bedrijfsleven en de VEB en Eumedion van investeerderszijde) heeft zich deze problematiek aangetrokken en startte in maart 2020 een lobby voor een noodwet om het voor rechtspersonen als NV's en BV's, maar ook voor verenigingen, coöperaties en onderlinge waarborgmaatschappijen mogelijk te maken om virtuele vergaderingen te kunnen houden. ${ }^{2}$

Deze lobby is succesvol geweest, want op vrijdag 3 april 2020 stemde de ministerraad in met toezending van een noodwetsvoorstel naar de Raad van State. ${ }^{3}$ Het wetsvoorstel kende een ongekend korte voorbereidings- en behandelingstijd, nu ook de Raad van State binnen enkele dagen zijn advies vaststelde (maandag 6 april 2020). $\mathrm{Na}$ indiening van het wetsvoorstel Tijdelijke wet COVID-19 Justitie en Veiligheid ${ }^{4}$ bij de Tweede Kamer op woensdag 8 april 2020, heeft de Tweede Kamer het wetsvoorstel al op 16 april 2020 aangenomen. De Eerste Kamer heeft het wetsvoorstel vervolgens op 21 april 2020 zonder stemming aangenomen. De Tijdelijke wet COVID-19 Justitie en Veiligheid (hierna: Noodwet) is op 24 april 2020 in het Staatsblad verschenen en nog diezelfde dag in werking getreden. ${ }^{5}$ Nederland volgt hiermee landen als Italië, Luxem-

2. E. van Rijn, 'Bedrijven en beleggers willen noodwet voor virtuele vergadering van aandeelhouders', FD 24 maart 2020. Ook de NCR (brancheorganisatie voor coöperaties) spant zich namens coöperaties in voor deze noodwet.

3. Zie www.rijksoverheid.nl/regering/nieuws/2020/04/03/spoedwet geving-op-het-terrein-van-justitie-en-veiligheid?utm_medium=email.

4. Kamerstukken II 2019/20, 35434, nr. 2. Zie ook www.rijksoverheid.nl/ onderwerpen/coronavirus-covid-19/nieuws/2020/04/08/ spoedwetgeving-justitie-en-veiligheid-naar-tweede-kamer.

5. Wet van 22 april 2020, houdende tijdelijke voorzieningen op het terrein van het Ministerie van Justitie en Veiligheid in verband met de uitbraak van COVID-19 (Tijdelijke wet COVID-19 Justitie en Veiligheid), Stb. 2020, 124 en inwerkingtredingsbesluit, Stb. 2020, 126. burg, Frankrijk en Duitsland, waar in vergelijkbare regelingen wordt voorzien. ${ }^{6}$

In deze bijdrage bespreken wij de Noodwet, ${ }^{7}$ waarbij we ons beperken tot de voor rechtspersonen relevante bepalingen uit de Noodwet $^{8}$, met een specifieke focus op de beursvennootschap. ${ }^{9}$ Wij laten de bepaling over de vereniging van eigenaars buiten beschouwing. In paragraaf 2 lichten wij de huidige mogelijkheden voor het houden van een AVA of ledenvergadering toe. Vervolgens gaan wij in op de verschillende onderdelen uit de Noodwet (vergaderen via een elektronisch communicatiemiddel en vergaderen zonder dat aandeelhouders fysiek aanwezig zijn (par. 3), bestuursvergaderingen en vergaderingen van het toezichthoudende orgaan (par. 4) en uitstel van termijnen en verslaglegging (par. 5)). In paragraaf 6 komen het overgangsrecht, de inwerkingtreding en het verval van de wet aan de orde, waarna we in paragraaf 7 komen tot een afronding.

\section{De huidige wettelijke mogelijkheden voor AVA's en ledenvergaderingen}

Om de verspreiding van COVID-19 te beperken kan het fysiek bijeenkomen voor een ledenvergadering of AVA, maar ook van bestuurders, commissarissen en andere vergadergerechtigden, zoals de accountant, onwenselijk zijn. De huidige wet biedt hiertoe al enig soelaas, want sinds $2007^{10}$ kunnen de statuten van de verschillende rechtspersonen bepalen dat leden/aandeelhouders bevoegd (maar dus niet verplicht) zijn om, in persoon of bij schriftelijk gevolmachtigde, door middel van een elektronisch communicatiemiddel aan de vergadering deel te nemen, daarin het woord te voeren en het stemrecht uit te oefenen. Het gaat dan om een zogenoemde hybride vergadering, namelijk een vergadering waarin vergadergerechtigden naast voornoemde elektronische mogelijkheid ook nog steeds de gelegenheid hebben om de vergadering fysiek bij te wonen.

Voor het virtuele deel van deze hybride vergadering gelden drie voorwaarden: (1) leden/aandeelhouders kunnen via het elektronische communicatiemiddel worden geïdentificeerd; (2) leden/aandeelhouders kunnen via het elektronische com-

6. Kamerstukken II 2019/20, 35434, nr. 3, p. 12.

7. Zie over het wetsvoorstel M. van Olffen \& C.R. Nagtegaal, Tijdelijke wet COVID-19 - vergaderen rondom het coronavirus, Ondernemingsrecht 2020/XX.

8. Andere onderdelen van de Noodwet betreffen bijv. een tijdelijke voorziening voor het langs elektronische weg verlijden van notariële aktes en regelingen, waardoor fysieke zittingen in gerechtelijke procedures in burgerlijke, bestuursrechtelijke en strafrechtelijke zaken tijdelijk digitaal kunnen plaatsvinden.

9. De beursvennootschap is in de Noodwet niet nader gedefinieerd. Wij verstaan in deze bijdrage onder beursvennootschap een vennootschap waarvan de aandelen of met medewerking van de vennootschap uitgegeven certificaten zijn toegelaten tot de handel op een gereglementeerde markt als bedoeld in art. 1:1 Wft.

10. Wet van 20 oktober 2006 tot wijziging van Boek 2 van het Burgerlijk Wetboek ter bevordering van het gebruik van elektronische communicatiemiddelen bij besluitvorming in rechtspersonen, Stb. 2006, 525. Zie artt. 2:38, 2:117a en 2:227a BW. 


\section{Maandblad \\ Ondernemingsrecht}

municatiemiddel rechtstreeks kennisnemen van de verhandelingen ter vergadering; en (3) leden/aandeelhouders kunnen via het elektronische communicatiemiddel (al dan niet vooraf) het stemrecht uitoefenen. Deelname via het elektronische communicatiemiddel aan de beraadslaging, dus het woord voeren tijdens de vergadering, stelt de wet niet als vereiste maar als een statutaire mogelijkheid. ${ }^{11}$ Afgelopen AVA-seizoen (2019) hebben twee beursvennootschappen (KPN en ABN AMRO) een dergelijke hybride vergadering gehouden, waarin het (nog) niet mogelijk was om ter vergadering deel te nemen aan de discussie en om vragen te stellen. Dit AVA-seizoen zijn meerdere beursvennootschappen (mede als gevolg van de coronamaatregelen) 'omgegaan' en hebben een hybride AVA georganiseerd. Bij sommige beursvennootschappen werd dit nog na oproeping ingevoerd. ${ }^{12}$

Hoewel Boek 2 BW dus de faciliteiten biedt om een dergelijke hybride vergadering te houden, hebben niet alle rechtspersonen van deze mogelijkheid gebruik gemaakt in hun statuten. Rechtspersonen die geen statutaire regeling hebben om een hybride vergadering te houden, kunnen dus geen hybride vergadering houden. Aanpassing van de statuten is op dit moment geen optie, want daarvoor is nu juist een besluit nodig van de AVA of ledenvergadering. Daarnaast geldt dat bij een hybride vergadering, indien wel statutair mogelijk, aandeelhouders nog steeds het recht hebben om toch naar de fysieke vergadering te komen, waardoor aanvullende maatregelen ter voorkoming van het risico op verspreiding van corona nog altijd moeten worden getroffen.

Boek 2 BW kent op dit moment niet de mogelijkheid om een volledig 'virtuele vergadering' te houden. Wij beschouwen een volledig virtuele vergadering als een vergadering die niet langer op een fysieke plek wordt gehouden, maar alleen in een virtuele omgeving, en waarin aandeelhouders op afstand kunnen deelnemen, eventueel het woord kunnen voeren én kunnen stemmen. $^{13}$

De afgelopen periode hebben met name beursvennootschappen geworsteld met de invulling van hun AVA, steeds ingehaald door de ontwikkelingen en overheidsmaatregelen op het gebied van corona. Sommige beursvennootschappen hebben hun vergadering al gehouden, en hielden daarbij vast aan de traditionele AVA, met aanvullende maatregelen, zoals het stellen van een maximumaantal aandeelhouders dat zal worden toegelaten, aankondiging dat slechts een beperkt aantal bestuurders en commissarissen aanwezig zal zijn, de mogelijkheid om vooraf vragen te stellen die tijdens de vergadering zullen worden behandeld, en de mogelijkheid om de AVA via een livestream te volgen. Andere beursvennootschappen zijn

11. Zie ook G.J.C. Rensen \& R.A. Hagens, Hybride AV heeft de toekomst, Ondernemingsrecht 2019/88.

12. Door de voorgestelde terugwerkende kracht van de Noodwet zouden dergelijke gebreken mogelijkerwijs kunnen worden 'geheeld', zie par. 6 .

13. We zullen in het vervolg van deze bijdrage toelichten dat de Noodwet uitgaat van een ander concept van 'virtuele vergadering', namelijk een waarbij het kunnen stemmen geen verplicht element is. overgegaan tot het houden van een hybride vergadering, sommige beursvennootschappen zelfs nadat de AVA als een traditionele AVA was opgeroepen. Weer andere hebben hun AVA uitgesteld.

Beursvennootschappen (en ook andere rechtspersonen) zijn echter gebaat bij meer mogelijkheden om de AVA in coronatijden te organiseren. De Noodwet komt rechtspersonen op dit punt tegemoet. Om te voorkomen dat er twijfel bestaat over de rechtsgeldigheid van genomen besluiten indien een vergadering niet volgens de wet en de statuten verloopt, en om te voorkomen dat uitstel van een vergadering kan leiden tot het niet-naleven van wettelijke termijnen, strekt de Noodwet ertoe om tijdelijk afwijkingen van wettelijke en statutaire bepalingen inzake het houden van fysieke vergaderingen en daarmee verband houdende termijnen toe te staan en eventuele gevolgen daarvan te regelen. ${ }^{14}$

Beursvennootschappen die hun AVA al bijeen hebben geroepen of op het punt staan om dat te doen, moeten nu inventariseren of de Noodwet mogelijkheden biedt om nadere of andere keuzes te maken. Het is aan het bestuur om te bepalen op welke wijze de vergadering exact wordt ingericht. De Noodwet biedt met name extra mogelijkheden, zonder overigens deze mogelijkheden verplicht voor te schrijven. Wel zijn aan bepaalde mogelijkheden verplichtingen verbonden. Het daarvan gebruik maken betekent dan ook zorg dragen voor extra faciliteiten, hetgeen niet voor alle vennootschappen de aangewezen keuze zal zijn, bijvoorbeeld uit kostenoogpunt.

Paragraaf 4 van de Noodwet (art. 5 t/m 25) bevat de bepalingen voor rechtspersonen. Deze paragraaf is echter lastig leesbaar. Dit komt onder meer omdat steeds wordt verwezen naar een bestaande regel uit Boek 2 BW, waarna de Noodwet een tijdelijke voorziening geeft die ofwel aanvullend is op de bestaande regel uit Boek 2 BW, dan wel daarvan afwijkt. Voor de leesbaarheid van de Noodwet hebben wij aan het eind van deze bijdrage een handzaam schema opgenomen waaruit blijkt welke relevante regels uit Boek 2 BW (niet langer) van toepassing zijn, en of de Noodwet daarop aanvullende of afwijkende voorzieningen geeft (tabel 1). Daarnaast heeft dit uiteraard ook te maken met het feit dat sprake is van noodwetgeving: wetgeving die zeer snel tot stand is gekomen en bovendien een resultante is van de verschillende belangen van de rechtspersoon en de stakeholders. Wij gaan hierna in meer detail in op de verschillende onderdelen van de Noodwet.

14. Kamerstukken II 2019/20, 35434, nr. 3, p. 7. 


\section{Vergaderen via een elektronisch communicatiemiddel en vergaderen zonder dat aandeelhouders fysiek aanwezig zijn (art. 6 voor de vereniging, coöperatie en onderlinge waarborgmaatschappij, art. $10 \mathrm{t} / \mathrm{m} 14$ voor de $\mathrm{NV}$ en art. $17 \mathrm{t} / \mathrm{m} 21$ voor de BV) \\ 3.1 Vergaderen via elektronisch communicatiemiddel en vergaderen zonder dat aandeelhouders fysiek aanwezig zijn}

Het hoofdthema van de Noodwet is de mogelijkheid voor rechtspersonen om een AVA of ledenvergadering te houden die uitsluitend via een elektronisch communicatiemiddel is te volgen (art. 10 en 17 Noodwet). Daarnaast bestaat de mogelijkheid voor het bestuur om te bepalen dat aandeelhouders ${ }^{15}$ geen fysieke toegang meer hebben tot de vergadering (art. 6, 11 en 18 Noodwet). Voor beide varianten geldt dat moet zijn voldaan aan enkele voorwaarden (waarover later meer).

Wat hierbij direct opvalt, is dat de toelichting bij de Noodwet ${ }^{16}$ de hiervoor genoemde enkele mogelijkheid tot het elektronisch volgen van een vergadering beschouwt als een 'virtuele vergadering', terwijl niet (ook) wordt gerept over het elektronisch kunnen stemmen tijdens deze vergadering. Tot de publicatie van de Noodwet gingen wij, maar ook anderen met ons, ${ }^{17}$ ervan uit dat een virtuele vergadering betekende dat er niet langer een fysieke AVA plaatsvindt en dat in plaats daarvan vergadergerechtigden de vergadering volledig digitaal zullen bijwonen, daarin het woord kunnen voeren én daarin het stemrecht kunnen uitoefenen (zie ook par. 2). Dit in tegenstelling tot de zogenoemde hybride vergadering. De wetgever lijkt uit te gaan van een beperktere definitie van de virtuele vergadering: een rechtspersoon hoeft vergadergerechtigden niet de mogelijkheid te bieden om digitaal te stemmen, als ze de vergadering maar virtueel kunnen volgen. De rechtspersoon kan er wel voor kiezen dat aandeelhouders virtueel kunnen stemmen, zie ook hierna.

Uit de wettekst volgt niet direct hoe leden/aandeelhouders, indien deze niet de mogelijkheid krijgen om digitaal te stemmen, dan wel moeten kunnen stemmen in een dergelijke virtuele vergadering. De Nota naar aanleiding van het verslag ${ }^{18}$ biedt hier duidelijkheid. Omdat in Nederland pas zeer recent

15. De Noodwet laat in het midden of dit betekent dat alle aandeelhouders of ook bepaalde aandeelhouders de toegang kan worden ontzegd. Van Olffen \& Nagtegaal (2020) menen dat het mogelijk is dat bepaalde vergadergerechtigden de toegang wordt ontzegd. De wettekst lijkt daar inderdaad ruimte voor te bieden, maar wij vragen ons af of dit de bedoeling van de wetgever is geweest.

16. Zie de Nota n.a.v. het verslag (onopgemaakte versie), p. 17

17. Zie bijv. A. van der Krans, De toekomst van de AVA: fysiek, hybride of virtueel: leg de keuze bij de vennootschap, Ondernemingsrecht 2019/4, en eerder A. van der Krans, De virtuele aandeelhoudersvergadering (diss. Utrecht; IVOR nr. 64), Deventer: Kluwer 2009, p. 2-7 en T. Salemink \& C.D.J. Bulten, De digitale algemene vergadering van aandeelhouders, in: C.J.H. Jansen, B.A. Schuijling \& I.V. Aronstein (red.), Onderneming en digitalisering (O\&R nr. 116), Deventer: Wolters Kluwer 2019, hoofdstuk 12.

18. Zie de Nota n.a.v. het verslag (onopgemaakte versie), p. 17-18. bij enkele beursvennootschappen wordt geëxperimenteerd met elektronisch stemmen tijdens de vergadering, wordt aan het bestuur van rechtspersonen de bevoegdheid verleend om al dan niet in de mogelijkheid te voorzien om tijdens de vergadering via een elektronisch communicatiemiddel te stemmen (art. 14 Noodwet). Een dergelijk besluit wordt in de oproeping of bij de wijziging van de wijze van vergaderen vermeld (zie par. 3.3). Daarnaast wordt het mogelijk dat leden/ aandeelhouders uitsluitend kunnen stemmen door voorafgaand aan de vergadering een volmacht of steminstructie aan een daartoe door de rechtspersoon aangewezen gevolmachtigde te geven. In dat geval kunnen bijvoorbeeld volmachten of steminstructies via een elektronisch communicatiemiddel worden gegeven aan de daartoe in de oproeping vermelde persoon die op basis daarvan in staat wordt gesteld (elektronisch) te stemmen. Dit kan ertoe leiden dat alleen de in de oproeping gemelde persoon de bevoegdheid krijgt om daadwerkelijk digitaal of per brief in de vergadering te stemmen, en anderen dus niet. Wij achten dit een goede praktische oplossing.

\subsection{Voorwaarden}

Zoals hiervoor vermeld kan het bestuur bepalen dat, in plaats van een fysieke vergadering, een AVA wordt gehouden die uitsluitend via een elektronisch communicatiemiddel is te volgen. Het bestuur kan echter ook bepalen dat aandeelhouders of leden geen fysieke toegang hebben tot de AVA, hetgeen dus betekent dat er in dat geval nog wel sprake is van een fysieke vergadering. Voor beide varianten gelden de volgende voorwaarden.

Ten eerste moeten vergadergerechtigden de vergadering via een elektronisch communicatiemiddel kunnen volgen, bijvoorbeeld via een livestream (via audio of video).

De tweede voorwaarde betreft het kunnen stellen van vragen door vergadergerechtigden voorafgaand aan de vergadering. Rechtspersonen stellen leden/aandeelhouders tot minimaal 72 uur voor de vergadering in de gelegenheid om schriftelijk of elektronisch vragen te stellen over de onderwerpen die op de agenda staan. De rechtspersoon kan een kortere termijn hanteren. De rechtspersoon dient deze vragen uiterlijk op de vergadering zelf te beantwoorden (al dan niet op thematische wijze gebundeld). De antwoorden worden tevens op de website van de rechtspersoon geplaatst of via een elektronisch communicatiemiddel toegankelijk gemaakt voor de aandeelhouders/ leden.

Ten derde dient het bestuur ervoor te zorgen dat ook tijdens de vergadering langs elektronische weg of anderszins nadere vragen kunnen worden gesteld, tenzij dit in het licht van de omstandigheden van dat moment in redelijkheid niet kan 


\section{Maandblad \\ Ondernemingsrecht}

worden gevergd. ${ }^{19}$ De voorzitter van de vergadering kan hier net als in een fysieke AVA de vergaderorde bewaken, bijvoorbeeld als blijkt dat er te veel vragen worden gesteld (zie ook par. 3.4).

De Noodwet bepaalt dat een afwijking van de verplichting tot publicatie van de antwoorden en de verplichting tot het bieden van de mogelijkheid om ook tijdens de vergadering vervolgvragen te kunnen stellen, geen gevolgen heeft voor de rechtsgeldigheid van de besluitvorming. Het is aan de rechtspersoon om hier redelijkerwijze mee om te gaan. De Noodwet beoogt een belangenafweging te maken tussen aan de ene kant het belang van de leden/aandeelhouders om zo veel als mogelijk te kunnen deelnemen aan de virtuele vergadering als ware het een fysieke vergadering en aan de andere kant het veiligstellen van het belang van de rechtspersoon wanneer dergelijke faciliteiten voor de leden/aandeelhouders in redelijkheid niet van hem kunnen worden gevergd.

De toelichting bij de Noodwet bepaalt ten aanzien van beursvennootschappen dat deze in ieder geval belangenorganisaties als VEB, Eumedion en VBDO de mogelijkheid zouden moeten geven om tijdens de vergadering vervolgvragen te stellen via een door de vennootschap aangewezen elektronisch communicatiemiddel. Deze organisaties moeten dan wel ook voorafgaand aan de vergadering schriftelijke vragen hebben ingediend. Een andere mogelijkheid die de toelichting bij de Noodwet geeft, is dat het bestuur van rechtspersonen vóór de vergadering een e-mail stuurt aan de leden/aandeelhouders met gestelde vragen en antwoorden, zodat zij daarvan kennis kunnen nemen. ${ }^{20}$

Rechtspersonen moeten bepalen hoe zij leden/aandeelhouders in de gelegenheid willen stellen om hun vragen voorafgaand aan en tijdens de vergadering in te dienen. Dergelijke vragen kunnen bijvoorbeeld worden gesteld door een e-mailadres voor dit doel open te stellen, of, als het aantal leden/aandeelhouders en de wijze van vergaderen dat toelaten, via een chatfunctie of app. Rechtspersonen dienen na te gaan hoe zij dit proces zo efficiënt mogelijk kunnen structureren, bijvoorbeeld door gebruik te maken van een moderator of door vragen te bundelen en, waar nodig, door de vergadering tijdelijk on hold te zetten, terwijl zij gegroepeerde antwoorden voorbereiden. Aandachtspunt hierbij is dat het proces technisch zo moet zijn ingericht dat rechtspersonen de identiteit kunnen controleren van aandeelhouders die vragen en vervolgvragen indienen.

\subsection{Oproeping}

NV's en BV's die kiezen voor de variant uit artikel 10/17 van de Noodwet dienen bij de oproeping te vermelden dat de

19. Kamerstukken II 2019/20, 35434, nr. 3, p. 8-9. Opvallend is dat de minister bij de BV (art. 18) en de vereniging (art. 6) op dit punt heeft gekozen voor een inspanningsverplichting van het bestuur ('Het bestuur spant zich in (...)' en bij de NV de formulering van meer dwingende aard lijkt te zijn: 'Het bestuur zorgt er voor (...).' Deze keuze wordt niet nader toegelicht.

20. Kamerstukken II 2019/20, 35434, nr. 3, p. 8-9.
AVA uitsluitend langs elektronische weg toegankelijk is. Als de oproeping reeds is gepubliceerd (voor een gewone of hybride vergadering), kan het bestuur tot uiterlijk 48 uur voor het tijdstip van de vergadering alsnog tot deze wijze van vergaderen besluiten. Dit wordt aan de aandeelhouders kenbaar gemaakt op dezelfde wijze als de oproeping. Is dit het geval, dan kunnen aandeelhouders nog tot in ieder geval 36 uur voorafgaande aan de AVA vragen indienen. Als de wijze van vergaderen na oproeping wordt gewijzigd, ligt het volgens de toelichting bij de Noodwet in de rede dat de rechtspersoon zich inspant om vergadergerechtigden die zich hadden voorgenomen aanwezig te zijn, zo goed mogelijk te faciliteren om langs elektronische weg deel te nemen en te stemmen, bijvoorbeeld door het beschikbaar stellen van een gevolmachtigde voor aandeelhouders. ${ }^{21}$

Bij de NV kan eveneens tot 48 uur voor de AVA worden besloten de plaats van de vergadering te wijzigen, bijvoorbeeld omdat de horecagelegenheid is gesloten vanwege de coronacrisis. Ook dit besluit wordt aan de aandeelhouders kenbaar gemaakt op dezelfde wijze als de oproeping. Deze mogelijkheid is overigens niet gecreëerd voor de BV. Deze keuze wordt niet toegelicht door de minister.

\subsection{Vergaderorde}

Net als bij een gewone fysieke vergadering draagt de voorzitter van een virtuele vergadering zorg voor een ordelijk en efficiënt verloop daarvan. ${ }^{22}$ De spelregels moeten bij de opening van de vergadering worden medegedeeld. Wij zouden aanraden de spelregels indien mogelijk al eerder op de website te publiceren. De toelichting bij de Noodwet geeft als voorbeelden van deze spelregels wie vragen mogen indienen, al of niet thematische beantwoording van vragen en het sluiten van een discussie. Met inachtneming van artikel 2:8 BW vinden op deze wijze onder deze uitzonderlijke omstandigheden een zo goed mogelijke dialoog en verantwoording plaats, aldus de toelichting. Mocht de verbinding hebben gehaperd of anderszins een lid/aandeelhouder niet optimaal hebben kunnen deelnemen aan de elektronische vergadering, dan heeft dit geen gevolgen voor de rechtsgeldigheid van de besluitvorming. Hiermee wordt voorkomen dat er onzekerheid bestaat over genomen besluiten afhankelijk van de invulling van de inspanningsverplichting van het bestuur. ${ }^{23}$

\subsection{Rechtsgeldigheid besluitvorming}

Het komt de rechtszekerheid ten goede dat in de Noodwet ten slotte is bepaald dat wanneer een lid of aandeelhouder niet optimaal heeft kunnen deelnemen aan de virtuele vergadering, de genomen besluiten toch rechtsgeldig zijn.

21. Kamerstukken II 2019/20, 35434, nr. 3, p. 9

22. Zie voor beursvennootschappen in dit kader ook best practice bepalingen 4.1.2 en 2.3.6 sub xi van de Nederlandse Corporate Governance Code. Zie ook B. Bier, Aandachtspunten voor de voorzitter van de algemene vergadering, in: B. Bier e.a., Jaarboek corporate governance: 2011-2012, Deventer: Kluwer 2011, p. 25-40.

23. Kamerstukken II 2019/20, 35434, nr. 3, p. 9. 


\section{Bestuursvergaderingen en vergaderingen van het toezichthoudende orgaan (art. 5 lid 4 en art. 23 voor de stichting)}

De Noodwet bevat ook een summiere regeling voor de vergaderingen van andere organen dan de AVA of ledenvergadering. Het kan voorkomen dat statutaire bepalingen regels bevatten voor het bijeenroepen of houden van vergaderingen van het bestuur of het toezichthoudende orgaan, ${ }^{24}$ of termijnen stellen. Om te voorkomen dat het bestuur of het toezichthoudende orgaan niet bijeen kan komen zonder in strijd met de statuten te handelen, bepaalt de Noodwet dat van dergelijke statutaire bepalingen kan worden afgeweken. Het bestuur en het toezichthoudende orgaan zullen dan met instemming van alle bestuurders respectievelijk toezichthouders op andere wijze de besluitvorming kunnen regelen, bijvoorbeeld langs elektronische weg. De Noodwet maakt het eveneens mogelijk dat het toezichthoudende orgaan van stichtingen of het orgaan dat de jaarrekening op grond van artikel 2:300 lid 3 BW vaststelt een vergadering kan houden met behulp van elektronische communicatiemiddelen. ${ }^{25}$

Daarnaast kan het voorkomen dat in de statuten besluiten van het bestuur aan de goedkeuring van een ander orgaan of een derde zijn onderworpen. Gelet op de bijzondere omstandigheden van het coronavirus, kan dit een belemmering voor het bestuur vormen om snel over te gaan tot de in de Noodwet toegekende bevoegdheden. Om die reden worden ook dergelijke statutaire bepalingen buiten toepassing verklaard. ${ }^{26}$

5 Uitstel van termijnen en verslaglegging (art. 7 voor de vereniging en de coöperatie, art. 8, 9 en 15 voor de NV, art. 16 en 22 voor de BV en art. 23 voor de stichting)

De NV dient ieder jaar ten minste één AVA te houden. De jaarlijkse AVA wordt doorgaans in het voorjaar gehouden, binnen zes maanden na afloop van het boekjaar. Daar wordt onder meer de jaarrekening vastgesteld, wordt decharge verleend aan bestuurders en commissarissen en kunnen bestuurders of commissarissen worden benoemd. De Noodwet maakt het mogelijk dat wanneer deze termijn vanwege de gevolgen van de coronacrisis niet kan worden gehaald, het bestuur van de NV de termijn voor het houden van een AVA met ten hoogste vier maanden kan verlengen. Op deze wijze kan de jaarvergadering na 30 juni 2020 worden uitgesteld tot uiterlijk 31 oktober 2020, mocht dit voor de NV en de daarbij betrokkenen beter uitkomen dan het houden van een AVA op elektronische wijze. Als het bestuur van een NV de termijn

24. Art. 5 lid 4 van de Noodwet verwijst naar de raad van commissarissen, maar wij gaan ervan uit dat de wetgever hier het toezichthoudende orgaan heeft bedoeld omdat de Noodwet ook van toepassing is op verenigingen, coöperaties en onderlinge waarborgmaatschappijen. Bovendien wordt in de toelichting bij de Nota van wijziging ten aanzien van de stichting expliciet gerefereerd aan het toezichthoudende orgaan (Nota van wijziging, onderdeel B).

25. Deze bepaling is toegevoegd bij Nota van wijziging, onderdeel B (onopgemaakte versie).

26. Kamerstukken II $2019 / 20,35434$, nr. 3 , p. 8 voor het opstellen van een jaarrekening verlengt, staat dit niet in de weg aan de inkoop van volgestorte aandelen. ${ }^{27}$ De verplichting voor verenigingen, coöperaties, onderlinge waarborgmaatschappijen en BV's om jaarlijks een AVA of ledenvergadering te houden blijft ongewijzigd.

De Noodwet bepaalt daarnaast dat de termijn voor verslaglegging door het bestuur van verenigingen, coöperaties, stichtingen, NV's en BV's kan worden verlengd. Voor verenigingen, coöperaties en stichtingen is de verlenging ten hoogste vier maanden, voor NV's en BV's is de verlenging ten hoogste vijf maanden. Maakt het bestuur van deze mogelijkheid gebruik, dan heeft de AVA (of bij de stichting: het volgens de statuten bevoegde orgaan) geen bevoegdheid tot verlenging. De uitstelmogelijkheid wordt niet gecreëerd voor beursvennootschappen omdat uitstel voor deze vennootschappen te ingrijpende gevolgen voor deze vennootschappen zou hebben, vooral voor hun positie op de kapitaalmarkt. Bovendien wijst de toelichting bij de Noodwet erop dat de AFM als toezichthouder, indien nodig in verband met het COVID-19-virus, coulance kan betrachten bij de handhaving. ${ }^{28}$

Het vanwege corona-gerelateerde oorzaken niet tijdig deponeren van de jaarrekening geldt tijdelijk niet als kennelijk onbehoorlijke taakvervulling die leidt tot een wettelijk bewijsvermoeden voor bestuurdersaansprakelijkheid in geval van faillissement (art. 2:138/248 BW). Het bestuur dient aan te tonen dat het verzuim van de publicatieplicht te wijten is aan de gevolgen van het COVID-19-virus. Het bestuur wordt wel geacht aan de boekhoudplicht van artikel 2:10 BW te kunnen voldoen. Daarvoor blijft het bewijsvermoeden onverkort gelden. ${ }^{29}$

\section{Overgangsrecht en inwerkingtreding en verval van de wet}

De regels hebben terugwerkende kracht tot 16 maart $2020 .^{30}$ Indien een AVA of ledenvergadering is gehouden voordat de wet (met terugwerkende kracht) in werking is getreden en met betrekking tot die vergadering gebruik is gemaakt van elektronische middelen terwijl de statuten dat niet toestaan, worden de in die vergadering genomen besluiten geacht geldig te zijn, voor zover zij op grond van de Noodwet geldig zouden zijn. ${ }^{31}$

De Noodwet is daarnaast een tijdelijke wet. In beginsel vervalt de wet per 1 september 2020. Hiervan kan bij koninklijk besluit worden afgeweken. De wet heeft aldus betrekking op AVA's waarop de jaarrekening over het boekjaar 2019 wordt vastgesteld. Ook in geval van gebroken boekjaren kan van de regeling gebruik worden gemaakt. De regeling over het bewijs-

27. Kamerstukken II 2019/20, 35434, nr. 3, p. 7, 8 en 10.

28. Kamerstukken II 2019/20, 35434, nr. 3, p. 10.

29. Kamerstukken II 2019/20, 35434, nr. 3, p. 9.

30. Het wetsvoorstel ging eerst uit van 23 maart 2020 maar omdat reeds vanaf 16 maart 2020 maatregelen in verband met de uitbraak van COVID-19 zijn getroffen, is bij Nota van wijziging, onderdeel E, voorgesteld om terugwerkende kracht tot en met die datum mogelijk te maken.

31. Kamerstukken II 2019/20, 35434, nr. 3, p. 11. 


\section{Maandblad \\ Ondernemingsrecht}

vermoeden vervalt per 1 september 2023. Dit hangt samen met de termijn waarvoor een vordering op grond van artikel 2:138/248 BW kan worden ingesteld..$^{32}$

\section{Afronding}

De Noodwet biedt rechtspersonen verschillende mogelijkheden om ondanks de gevolgen van de coronacrisis hun raadsvergadering, AVA of ledenvergadering te plannen en te houden op een manier die voor hen passend is. Welke vergadervorm het meest geschikt is, wordt uiteindelijk bepaald door het bestuur van de rechtspersoon.

Rechtspersonen die hun AVA of ledenvergadering nog moeten oproepen, staan voor de keuze om gebruik te maken van de mogelijkheden en varianten die de Noodwet biedt. Ook rechtspersonen die een vergadering reeds hebben opgeroepen, kunnen nog besluiten om de eerder gekozen wijze van vergaderen aan te passen. Sommige rechtspersonen zullen wellicht niet veel toegevoegde waarde zien in de Noodwet, het blijft tenslotte mogelijk om een traditionele of hybride vergadering te houden, met aanvullende praktische maatregelen zoals hiervoor gemeld. Wij verwachten wel dat op beursvennootschappen die hun AVA nog moeten houden in meer of mindere mate de druk komt te liggen om te bekijken of de Noodwet extra mogelijkheden biedt om de vergadering zo goed mogelijk te laten verlopen. Dit is uiteraard afhankelijk van het type vennootschap, of zij bijvoorbeeld ervaring hebben met het elektronisch vergaderen en hoeveel aandeelhouders gebruikelijk tijdens de AVA aanwezig zijn.

De Noodwet biedt enkele interessante features. Samengevat hebben rechtspersonen de volgende mogelijkheden:

- NV's en BV's kunnen besluiten tot het houden van een AVA die uitsluitend via een elektronisch communicatiemiddel is te volgen. Het bestuur kan daarbij bepalen hoe het stemrecht wordt uitgeoefend: via een elektronisch communicatiemiddel of door voorafgaand aan de vergadering een volmacht of steminstructie aan een daartoe door de rechtspersoon aangewezen gevolmachtigde te geven.

- Rechtspersonen kunnen bepalen dat vergadergerechtigden geen fysieke toegang hebben tot de AVA. Voor deze eerste twee mogelijkheden gelden nadere voorwaarden: de mogelijkheid tot het volgen van de vergadering via een elektronisch communicatiemiddel en het kunnen stellen van vragen voorafgaand aan en tijdens de vergadering.

- NV's en BV's kunnen tot 48 uur voor de vergadering hun wijze van vergaderen wijzigen.

- NV's kunnen tot 48 uur voor de vergadering besluiten om de vergaderlocatie te wijzigen.

- Het houden van een hybride vergadering wordt voor elke rechtspersoon mogelijk gemaakt, ook als dit niet in de statuten is opgenomen.
- Eventuele statutaire belemmeringen voor vergaderingen van het bestuur of de raad van commissarissen van rechtspersonen worden weggenomen.

- NV's kunnen hun AVA uitstellen.

- Rechtspersonen kunnen de termijn voor hun verslaglegging verlengen.

Ten slotte dient de Noodwet de rechtszekerheid door regels te geven over de rechtsgeldigheid van de besluitvorming die in het licht van de coronamaatregelen worden genomen.

Kortom, mogelijkheden te over, die door de Noodwet nader worden gefaciliteerd. Wel is het jammer dat de wetgever het niet mogelijk heeft gemaakt om de oproepingstermijn van 42 dagen voor de AVA te verkorten alsmede de daarbij behorende termijn voor de registratiedatum. Wij kijken bovendien uit naar de periode na 1 september 2020. Niet alleen omdat we dan hopelijk de coronacrisis weer enigszins te boven zijn, maar ook omdat wij graag een levendige discussie zouden zien ontstaan over het invoeren van een definitieve regeling voor het houden van een virtuele vergadering.

32. Kamerstukken II 2019/20, 35434, nr. 3, p. 11-12. 


\section{Maandblad}

Ondernemingsrecht

Tabel 1 Overzicht van bepalingen in de Tijdelijke wet COVID-19 Justitie en Veiligheid (de Noodwet) in verhouding tot bepaalde regelingen uit Boek $2 \mathrm{BW}$

\begin{tabular}{llll}
\hline $\begin{array}{l}\text { Artikel } \\
\text { Nood- } \\
\text { wet }\end{array}$ & $\begin{array}{l}\text { Betreffen- } \\
\text { de rechts- } \\
\text { persoon }\end{array}$ & $\begin{array}{l}\text { Relevante } \\
\text { wettelijke } \\
\text { bepaling }\end{array}$ & Tekst wettelijke bepaling \\
\hline 5 & N.v.t. & N.v.t. & N.v.t.
\end{tabular}

Vereniging Art. 2:38 lid 1 Behoudens het in het volgende artikel BW bepaalde, hebben alle leden die niet geschorst zijn, toegang tot de algemene vergadering en hebben daar ieder één stem; een geschorst lid heeft toegang tot de vergadering waarin het besluit tot schorsing wordt behandeld, en is bevoegd daarover het woord te voeren. De statuten kunnen aan bepaalde leden meer dan één stem toekennen.
Bepaling Noodwet

1. Met het oog op de gevolgen van het houden van fysieke bijeenkomsten in verband met de uitbraak van COVID-19, kan op de aangegeven wijze worden afgeweken van de in deze paragraaf genoemde bepalingen in Boek 2 van het Burgerlijk Wetboek.

2. De artikelen in deze paragraaf verwijzen naar Boek 2 van het Burgerlijk Wetboek, tenzij anders vermeld.

3. Waar in deze paragraaf wordt afgeweken ten behoeve van leden of aandeelhouders, worden daaronder ook andere vergadergerechtigden begrepen.

4. Waar in deze paragraaf wordt afgeweken van bepalingen in Boek 2 van het Burgerlijk Wetboek, worden daaronder ook statutaire bepalingen met dezelfde inhoud begrepen. Statutaire bepalingen aangaande het fysiek bijeenkomen van het bestuur, de raad van commissarissen en de algemene vergadering en statutaire bepalingen die de uitoefening van in deze paragraaf aan het bestuur toegekende bevoegdheden beperken of aan de goedkeuring van een ander orgaan of een derde onderwerpen, zijn niet van toepassing.

1. In afwijking van artikel 38 lid 1 kan het bestuur bepalen dat leden geen fysieke toegang hebben tot de algemene vergadering, onder de volgende voorwaarden:

a. de algemene vergadering is langs elektronisch weg voor leden te volgen; en

b. de leden zijn tot uiterlijk 72 uur voorafgaand aan de vergadering in de gelegenheid gesteld om schriftelijk of elektronisch vragen te stellen over de onderwerpen die bij de oproeping zijn vermeld.

2. De in lid 1 onder $b$ bedoelde vragen worden uiterlijk tijdens de vergadering, al dan niet thematisch, beantwoord en deze antwoorden worden op de website van de vereniging geplaatst of via een elektronisch communicatiemiddel toegankelijk gemaakt voor de leden.

3. Het bestuur spant zich ervoor in dat tijdens de vergadering langs elektronische weg of anderszins nadere vragen kunnen worden gesteld, tenzij dit in het licht van de omstandigheden van dat moment in redelijkheid niet kan 


\section{Maandblad}

Ondernemingsrecht

Tabel $1 \quad$ (Vervolg)

\begin{tabular}{llll}
\hline Artikel & Betreffen- & Relevante & Tekst wettelijke bepaling \\
Nood- & de rechts- & wettelijke & \\
wet & persoon & bepaling & \\
\hline
\end{tabular}

Art. 2:38 lid 3 De statuten kunnen bepalen dat personen BW die deel uitmaken van andere organen der vereniging en die geen lid zijn, in de algemene vergadering stemrecht kunnen uitoefenen. Het aantal der door hen gezamenlijk uitgebrachte stemmen zal echter niet meer mogen zijn dan de helft van het aantal der door de leden uitgebrachte stemmen.

Art. 2:38 lid 6 De statuten kunnen bepalen dat iemand die BW krachtens lid 1 of lid 3 stemgerechtigd is het stemrecht kan uitoefenen door middel van een elektronisch communicatiemiddel.

Art. 2:38 lid 8 De statuten kunnen bepalen dat stemmen BW die voorafgaand aan de algemene vergadering via een elektronisch communicatiemiddel worden uitgebracht, doch niet eerder dan op de dertigste dag voor die van de vergadering, gelijk worden gesteld met stemmen die ten tijde van de vergadering worden uitgebracht.

5. Voor zover de statuten zulks niet bepalen, kan, in aanvulling op artikel 38 lid 6, het bestuur bepalen dat het stemrecht slechts kan worden uitgeoefend door middel van een elektronisch communicatiemiddel.

6. Voor zover de statuten zulks niet bepalen, kan, in aanvulling op artikel 38 lid 8, het bestuur bepalen dat stemmen die voorafgaand aan de algemene vergadering door middel van een elektronisch communicatiemiddel worden uitgebracht gelijk worden gesteld met stemmen die ten tijde van de vergadering worden uitgebracht.

Vereniging Art. 2:48 lid 1 Het bestuur brengt op een algemene vergaBW dering binnen zes maanden na afloop van het boekjaar, behoudens verlenging van deze termijn door de algemene vergadering, een bestuursverslag uit over de gang van zaken in de algemene vergadering geen bevoegdheid tot verde vereniging en over het gevoerde beleid. lenging. Het legt de balans en de staat van baten en lasten met een toelichting ter goedkeuring aan de vergadering over. Deze stukken worden ondertekend door de bestuurders en commissarissen; ontbreekt de ondertekening van een of meer hunner, dan wordt daarvan onder opgave van redenen melding gemaakt. Na verloop van de termijn kan ieder lid van de gezamenlijke bestuurders in rechte vorderen dat zij deze verplichtingen nakomen.

In afwijking van de artikelen 48 lid 1, 49 lid 1 en 58 lid 1 kan de termijn van zes maanden na afloop van het boekjaar door het bestuur worden verlengd met ten hoogste vier maanden. In dat geval heeft 


\section{Maandblad}

Ondernemingsrecht

Tabel $1 \quad$ (Vervolg)

\begin{tabular}{lllll}
\hline Artikel & Betreffen- & Relevante & Tekst wettelijke bepaling & Bepaling Noodwet \\
Nood- & de rechts- & wettelijke & & \\
wet & persoon & bepaling & &
\end{tabular}

Art. 2:49 lid 1 Jaarlijks binnen zes maanden na afloop van BW het boekjaar van een vereniging als bedoeld in artikel 360 lid 3, behoudens verlenging van deze termijn met ten hoogste vier maanden door de algemene vergadering op grond van bijzondere omstandigheden, maakt het bestuur een jaarrekening op en legt het deze voor de leden ter inzage ten kantore van de vereniging. Binnen deze termijn legt het bestuur ook het bestuursverslag ter inzage voor de leden, tenzij de artikelen 396 lid 7 of 403 voor de vereniging gelden.

Coöperatie Art. 2:58 lid 1 Jaarlijks binnen zes maanden na afloop van BW het boekjaar, behoudens verlenging van deze termijn met ten hoogste vier maanden door de algemene vergadering op grond van bijzondere omstandigheden, maakt het bestuur een jaarrekening op en legt het deze voor de leden ter inzage ten kantore van de rechtspersoon. Binnen deze termijn legt het bestuur ook het bestuursverslag ter inzage voor de leden, tenzij de artikelen 396 lid 7, of 403 voor de rechtspersoon gelden. De jaarrekening wordt vastgesteld door de algemene vergadering die het bestuur uiterlijk een maand na afloop van de termijn doet houden. Artikel 48 lid 2 is van overeenkomstige toepassing. Vaststelling van de jaarrekening strekt niet tot kwijting aan een bestuurder onderscheidenlijk commissaris.

Art. 2:98 lid 2 Volgestorte eigen aandelen mag de vennootBW schap slechts verkrijgen om niet of indien het eigen vermogen, verminderd met de verkrijgingsprijs, niet kleiner is dan het gestorte en opgevraagde deel van het kapitaal, vermeerderd met de reserves die krachtens de wet of de statuten moeten worden aangehouden. Onverminderd het bepaalde in de vorige zin beloopt, indien de aandelen van de vennootschap zijn toegelaten tot de handel op een gereglementeerde markt of op een multilaterale handelsfaciliteit, als bedoeld in artikel 1:1 van de Wet op het financieel toezicht of een met een gereglementeerde markt of multilaterale handelsfaciliteit vergelijkbaar systeem uit een staat die geen lidstaat is, het nominale bedrag van de 


\section{Maandblad}

Ondernemingsrecht

Tabel $1 \quad$ (Vervolg)

\begin{tabular}{lllll}
\hline $\begin{array}{l}\text { Artikel } \\
\text { Nood- } \\
\text { wet }\end{array}$ & $\begin{array}{l}\text { Betreffen- } \\
\text { de rechts- } \\
\text { persoon }\end{array}$ & $\begin{array}{l}\text { Relevante } \\
\text { wettelijke } \\
\text { bepaling }\end{array}$ & Tekst wettelijke bepaling & Bepaling Noodwet \\
\hline
\end{tabular}

aandelen in haar kapitaal die de vennootschap verkrijgt, houdt of in pand houdt of die worden gehouden door een dochtermaatschappij, niet meer dan de helft van het geplaatste kapitaal.

Art. 2:98 lid 3 Voor het vereiste in lid 2 is bepalend de BW grootte van het eigen vermogen volgens de laatst vastgestelde balans, verminderd met de verkrijgingsprijs voor aandelen in het kapitaal van de vennootschap, het bedrag van leningen als bedoeld in artikel 98c lid 2 en uitkeringen uit winst of reserves aan anderen die zij en haar dochtermaatschappijen na de balansdatum verschuldigd werden. Is een boekjaar meer dan zes maanden verstreken zonder dat de jaarrekening is vastgesteld, dan is verkrijging overeenkomstig lid 2 niet toegestaan.

Art. 2:101 lid Jaarlijks binnen vijf maanden na afloop van $1 \mathrm{BW} \quad$ het boekjaar der vennootschap, behoudens verlenging van deze termijn met ten hoogste vijf maanden door de algemene vergadering op grond van bijzondere omstandigheden, makkt het bestuur een jaarrekening op en legt het deze voor de aandeelhouders ter inzage ten kantore van de vennootschap. Indien van de vennootschap effecten zijn toegelaten tot de handel op eengereglementeerde markt als bedoeld in de Wet op het financieel toezicht, bedraagt de termijn vier maanden, tenzij artikel 5:25g, tweede of derde lid, van die wet van toepassing is. Deze termijn kan niet worden verlengd. Binnen deze termijn legt het bestuur ook het bestuursverslag ter inzage voor de aandeelhouders, tenzij de artikelen 396 lid 7, of 403 voor de vennootschap gelden. Het bestuur van de vennootschap waarop de artikelen 158 tot en met 161 en 164 van toepassing zijn, zendt de jaarrekening ook toe aan de in artikel 158 lid 11 bedoelde ondernemingsraad.

Art. 2:108 lid Wanneer bij de statuten niet een kortere $2 \mathrm{BW}$ termijn is gesteld, wordt de jaarvergadering gehouden binnen zes maanden na afloop van het boekjaar der vennootschap.
In afwijking van artikel 101 lid 1 kan de termijn van vijf maanden na afloop van het boekjaar door het bestuur worden verlengd met ten hoogste vijf maanden. In dat geval heeft de algemene vergadering geen bevoegdheid tot verlenging en is de laatste zin van artikel 98 lid 3 niet van toepassing.

In afwijking van artikel 108 lid 2 kan de termijn van zes maanden na afloop van het boekjaar of de in de statuten gestelde kortere termijn door het bestuur worden verlengd met ten hoogste vier maanden. 


\section{Maandblad}

Ondernemingsrecht

\section{Tabel 1 (Vervolg)}

\begin{tabular}{llll}
\hline $\begin{array}{l}\text { Artikel } \\
\text { Nood- } \\
\text { wet }\end{array}$ & $\begin{array}{l}\text { Betreffen- } \\
\text { de rechts- } \\
\text { persoon }\end{array}$ & $\begin{array}{l}\text { Relevante } \\
\text { wettelijke } \\
\text { bepaling }\end{array}$ & Tekst wettelijke bepaling \\
\hline 10 & NV & Art. 2:116 & \\
& BW & $\begin{array}{l}\text { De algemene vergaderingen worden gehou- } \\
\text { den in Nederland ter plaatse bij de statuten } \\
\text { vermeld, of anders in de gemeente waar de } \\
\text { naamloze vennootschap haar woonplaats } \\
\text { heeft. In een algemene vergadering, gehou- } \\
\text { den elders dan behoort, kunnen wettige } \\
\text { besluiten slechts worden genomen, indien } \\
\text { het gehele geplaatste kapitaal vertegenwoor- } \\
\text { digd is. }\end{array}$
\end{tabular}

Bepaling Noodwet

1. In afwijking van artikel 116 kan het bestuur bepalen dat een algemene vergadering wordt gehouden die uitsluitend toegankelijk is langs elektronische weg, onder de voorwaarden bedoeld in artikel 11 van deze wet. Dit wordt bij de oproeping, bedoeld in artikel 113, vermeld.

2. Indien de oproeping reeds is uitgegaan, kan het bestuur tot uiterlijk 48 uur voor het tijdstip van de algemene vergadering, de wijze van vergaderen wijzigen in een vergadering als bedoeld in het eerste lid dan wel de plaats van de vergadering kan wijzigen. Dit wordt aan de aandeelhouders kenbaar gemaakt op de wijze zoals voorgeschreven in artikel 113.

Art. 2:117 lid Iedere aandeelhouder is bevoegd, in persoon $1 \mathrm{BW}$ of bij een schriftelijk gevolmachtigde, de algemene vergaderingen bij te wonen, daarin het woord te voeren en het stemrecht uit te oefenen. Houders van onderaandelen, tezamen uitmakende het bedrag van een aandeel, oefenen deze rechten gezamenlijk uit, hetzij door één van hen, hetzij door een schriftelijk gevolmachtigde. Bij de statuten kan de bevoegdheid van aandeelhouders zich te doen vertegenwoordigen, worden beperkt. De bevoegdheid van aandeelhouders zich te doen vertegenwoordigen door een advocaat, notaris, toegevoegd notaris, kandidaat-notaris, registeraccountant of accountant-administratieconsulent kan niet worden uitgesloten.

1. In afwijking van artikel 117 , lid 1 kan het bestuur bepalen dat aandeelhouders geen fysieke toegang hebben tot de algemene vergadering, onder de volgende voorwaarden:

a. de algemene vergadering is langs elektronische weg voor aandeelhouders te volgen; en

b. de aandeelhouders zijn tot uiterlijk 72 uur voorafgaand aan de vergadering in de gelegenheid gesteld om schriftelijk of elektronisch vragen te stellen over de onderwerpen die bij de oproeping zijn vermeld. Wordt een besluit in de zin van artikel 10 lid 2 van deze wet genomen binnen vijf dagen voorafgaand aan de datum van de vergadering, dan is de hiervoor bedoelde termijn 36 uur.

2. De in lid 1 onder $b$ bedoelde vragen worden uiterlijk tijdens de vergadering, al dan niet thematisch, beantwoord en deze antwoorden worden op de website van de vennootschap geplaatst of via een elektronisch communicatiemiddel toegankelijk gemaakt voor de aandeelhouders.

3. Het bestuur zorgt er voor dat tijdens de vergadering langs elektronische weg of anderszins nadere vragen kunnen worden gesteld, tenzij dit in het licht van de omstandigheden van dat moment in redelijkheid niet kan worden gevergd. De voorzitter van de vergadering kan een en ander nader bepalen in het belang van de orde van de vergadering.

4. Enige afwijking van de leden 2 en 3 heeft geen gevolgen voor de rechtsgeldigheid. 


\section{Maandblad}

Ondernemingsrecht

Tabel $1 \quad$ (Vervolg)

\begin{tabular}{lllll}
\hline $\begin{array}{l}\text { Artikel } \\
\text { Nood- }\end{array}$ & $\begin{array}{l}\text { Betreffen- } \\
\text { de rechts- }\end{array}$ & $\begin{array}{l}\text { Relevante } \\
\text { wettelijke }\end{array}$ & Tekst wettelijke bepaling & Bepaling Noodwet \\
wet & persoon & bepaling & & \\
\hline
\end{tabular}

$12 \quad$ NV Art. 2:117a $\quad$ De statuten kunnen bepalen dat iedere aan- Voor zover de statuten zulks niet bepalen, kan, in lid $1 \mathrm{BW}$ deelhouder bevoegd is om, in persoon of bij aanvulling op artikel 117a lid 1, het bestuur bepaeen schriftelijk gevolmachtigde, door middel len dat iedere aandeelhouder bevoegd is om, in van een elektronisch communicatiemiddel persoon of bij een schriftelijk gevolmachtigde, aan de algemene vergadering deel te nemen, langs elektronische weg aan de algemene vergadedaarin het woord te voeren en het stemrecht ring deel te nemen, daarin het woord te voeren en uit te oefenen. het stemrecht uit te oefenen.

Art. 2:117b lid $1 \mathrm{BW}$

Art. 2:117b lid 2 BW
De statuten kunnen bepalen dat stemmen die voorafgaand aan de algemene vergadering via een elektronisch communicatiemiddel of bij brief worden uitgebracht gelijk worden gesteld met stemmen die ten tijde van de vergadering worden uitgebracht. Deze stemmen worden niet eerder uitgebracht dan op de in het derde lid bedoelde dag van registratie.

Voor de toepassing van lid 1 hebben als stem- of vergadergerechtigde te gelden zij die op een bij de bijeenroeping van een algemene vergadering te bepalen tijdstip die rechten hebben en als zodanig zijn ingeschreven in een door het bestuur aangewezen register, ongeacht wie ten tijde van de algemene vergadering de rechthebbenden op de aandelen zijn.

Art. 2:118 lid Slechts aandeelhouders hebben stemrecht. $1 \mathrm{BW} \quad$ Iedere aandeelhouder heeft ten minste één stem. De statuten kunnen bepalen dat een aandeelhouder niet gerechtigd is tot uitoefening van het stemrecht zolang hij in gebreke is te voldoen aan een wettelijke of statutaire verplichting.

Art. 2:138 lid Indien het bestuur niet heeft voldaan aan $2 \mathrm{BW}$ verplichtingen uit de artikelen 10 of
Voor zover de statuten zulks niet bepalen, kan, in aanvulling op artikel $117 \mathrm{~b}$ lid 1 , het bestuur bepa-

len dat stemmen die voorafgaand aan de algemene vergadering door middel van een elektronisch communicatiemiddel of bij brief worden uitgebracht, gelijk worden gesteld met stemmen die ten tijde van de vergadering worden uitgebracht. Dit wordt bij de oproeping of bij de wijziging van de wijze van vergaderen vermeld.

In afwijking van artikel $117 \mathrm{~b}$ lid 2 kan het tijdstip worden bepaald bij de wijziging van de wijze van vergaderen als bedoeld in artikel 10 lid 2 van deze wet.

In aanvulling op artikel 118 lid 1 kan het bestuur bepalen dat het stemrecht slechts kan worden uitgeoefend door middel van een elektronisch communicatiemiddel. Dit wordt bij de oproeping of bij de wijziging van de wijze van vergaderen vermeld.

In afwijking van artikel 138 lid 2 wordt een verzuim van de verplichting uit artikel 394 tot open394 , heeft het zijn taak onbehoorlijk vervuld en wordt vermoed dat onbehoorlijke taakvervulling een belangrijke oorzaak is van het faillissement. Hetzelfde geldt indien de vennootschap volledig aansprakelijk vennoot is van een vennootschap onder firma of commanditaire vennootschap en niet voldaan is aan de verplichtingen uit artikel $15 \mathrm{i}$ van Boek 3. Een onbelangrijk verzuim wordt niet in aanmerking genomen.

Art. 2:394 lid De rechtspersoon is verplicht tot openbaar$1 \mathrm{BW}$ making van de jaarrekening binnen acht baarmaking van de jaarrekening die betrekking heeft op het meest recente afgesloten boekjaar niet in aanmerking genomen, indien dat te wijten is aan de gevolgen van de uitbraak van COVID-19. 


\section{Maandblad}

Ondernemingsrecht

Tabel $1 \quad$ (Vervolg)

\begin{tabular}{lll}
\hline Artikel & Betreffen- & Relevante \\
Nood- & de rechts- & wettelijke \\
wet & persoon & bepaling
\end{tabular}

Tekst wettelijke bepaling

Bepaling Noodwet

dagen na de vaststelling. De openbaarma-

king geschiedt door deponering van de volledig in de Nederlandse taal gestelde jaarrekening of, als die niet is vervaardigd, de jaarrekening in het Frans, Duits of Engels, bij het handelsregister, indien van toepassing op de wijze als voorgeschreven bij of krachtens artikel 19a van de Handelsregisterwet 2007. De dag van vaststelling moet zijn vermeld.

Art. 2:394 lid Is de jaarrekening niet binnen twee maan$2 \mathrm{BW}$ den na afloop van de voor het opmaken voorgeschreven termijn overeenkomstig de wettelijke voorschriften vastgesteld, dan maakt het bestuur onverwijld de opgemaakte jaarrekening op de in lid 1 voorgeschreven wijze openbaar; op de jaarrekening wordt vermeld dat zij nog niet is vastgesteld. Binnen twee maanden na gerechtelijke vernietiging van een jaarrekening moet de rechtspersoon een afschrift van de in de uitspraak opgenomen bevelen met betrekking tot de jaarrekening deponeren bij het handelsregister, met vermelding van de uitspraak.

Art. 2:394 lid Uiterlijk twaalf maanden na afloop van het $3 \mathrm{BW} \quad$ boekjaar moet de rechtspersoon de jaarrekening op de in lid 1 voorgeschreven wijze openbaar hebben gemaakt. het boekjaar der vennootschap, behoudens verlenging van deze termijn met ten hoogste vijf maanden door de algemene vergadering op grond van bijzondere omstandigheden, makkt het bestuur een jaarrekening op en legt het deze voor de aandeelhouders ter inzage ten kantore van de vennootschap. Indien van de vennootschap effecten zijn toegelaten tot de handel op een gereglementeerde markt als bedoeld in de Wet op het financieel toezicht, bedraagt de termijn vier maanden, tenzij artikel 5:25g, tweede of derde lid, van die wet van toepassing is. Deze termijn kan niet worden verlengd. Binnen deze termijn legt het bestuur ook het bestuursverslag ter inzage voor de aandeelhouders, tenzij de artikelen 396 lid 7, of 403

In afwijking van artikel 210 lid 1 kan de termijn van vijf maanden na afloop van het boekjaar door het bestuur worden verlengd met ten hoogste vijf maanden. In dat geval heeft de algemene vergadering geen bevoegdheid tot verlenging. 


\section{Maandblad}

Ondernemingsrecht

Tabel 1 (Vervolg)

\begin{tabular}{|c|c|c|c|}
\hline $\begin{array}{l}\text { Artikel } \\
\text { Nood- } \\
\text { wet }\end{array}$ & $\begin{array}{l}\text { Betreffen- } \\
\text { de rechts- } \\
\text { persoon }\end{array}$ & $\begin{array}{l}\text { Relevante } \\
\text { wettelijke } \\
\text { bepaling }\end{array}$ & Tekst wettelijke bepaling \\
\hline & & & $\begin{array}{l}\text { voor de vennootschap gelden. Het bestuur } \\
\text { van de vennootschap waarop de artikelen } \\
268 \text { tot en met } 271 \text { en } 274 \text { van toepassing } \\
\text { zijn, zendt de jaarrekening ook toe aan de in } \\
\text { artikel } 268 \text { lid } 11 \text { bedoelde onder- } \\
\text { nemingsraad. }\end{array}$ \\
\hline 17 & BV & $\begin{array}{l}\text { Art. 2:226 lid } \\
1 \mathrm{BW}\end{array}$ & $\begin{array}{l}\text { De algemene vergadering wordt gehouden } \\
\text { ter plaatse bij de statuten vermeld of anders } \\
\text { in de gemeente waar de vennootschap haar } \\
\text { woonplaats heeft. De in de statuten vermel- } \\
\text { de plaats kan een plaats buiten Nederland } \\
\text { zijn. }\end{array}$ \\
\hline
\end{tabular}

Bepaling Noodwet

1. In afwijking van artikel 226 lid 1 kan het bestuur bepalen dat een algemene vergadering wordt gehouden die uitsluitend toegankelijk is langs elektronisch weg onder de voorwaarden bedoeld in artikel 18. Dit wordt bij de oproeping, bedoeld in artikel 223, vermeld.

2. Indien de oproeping reeds is uitgegaan, kan het bestuur tot uiterlijk 48 uur voor het tijdstip van de algemene vergadering de wijze van vergaderen wijzigen in een vergadering als bedoeld in het eerste lid. Dit wordt aan de aandeelhouders kenbaar gemaakt op de wijze zoals voorgeschreven in artikel 223.

Art. 2:227 lid Iedere aandeelhouder is bevoegd, in persoon $3 \mathrm{BW}$ of bij schriftelijk gevolmachtigde, het hem toekomende stemrecht uit te oefenen in de algemene vergadering. 


\section{Maandblad}

Ondernemingsrecht

Tabel 1 (Vervolg)

\begin{tabular}{lllll}
\hline Artikel & Betreffen- & Relevante & Tekst wettelijke bepaling & Bepaling Noodwet \\
Nood- & de rechts- & wettelijke & & \\
wet & persoon & bepaling & &
\end{tabular}

worden gevergd. De voorzitter van de vergadering kan een en ander nader bepalen in het belang van de orde van de vergadering.

4. Enige afwijking van hetgeen is bepaald in de leden 2 en 3 heeft geen gevolgen voor de rechtsgeldigheid van de besluitvorming die in de vergadering heeft plaatsgevonden.

2:227a lid 1 BW BW

Art. 2:228 lid Slechts aandeelhouders hebben stemrecht. $1 \mathrm{BW} \quad$ Iedere aandeelhouder heeft ten minste één stem. De statuten kunnen bepalen dat een aandeelhouder niet gerechtigd is tot uitoefening van het stemrecht zolang hij in gebreke is te voldoen aan een wettelijke of statutaire verplichting. uit te oefenen. die voorafgaand aan de algemene vergadedel worden uitgebracht, doch niet eerder gadering, gelijk worden gesteld met stemuitgebracht. zijn verplichtingen uit de artikelen 10 of en wordt vermoed dat onbehoorlijke taakfaillissement. Hetzelfde geldt indien de vennootschap volledig aansprakelijk vencommanditaire vennootschap en niet volvan Boek 3. Een onbelangrijk verzuim wordt niet in aanmerking genomen.
De statuten kunnen bepalen dat iedere aan- Voor zover de statuten zulks niet bepalen, kan, in deelhouder bevoegd is om, in persoon of bij afwijking van artikel 227a lid 1, het bestuur bepaeen schriftelijk gevolmachtigde, door middel len dat iedere aandeelhouder bevoegd is om, in van een elektronisch communicatiemiddel persoon of bij een schriftelijk gevolmachtigde, aan de algemene vergadering deel te nemen, langs elektronische weg aan de algemene vergadedaarin het woord te voeren en het stemrecht ring deel te nemen, daarin het woord te voeren en het stemrecht uit te oefenen.

Voor zover de statuten zulks niet bepalen, kan, in afwijking van artikel $227 \mathrm{~b}$, het bestuur bepalen dat ring via een elektronisch communicatiemiddan op de dertigste dag voor die van de vermen die ten tijde van de vergadering worden

stemmen die voorafgaand aan de algemene vergadering langs elektronische weg worden uitgebracht, doch niet eerder dan op de dertigste dag voor die van de vergadering, gelijk worden gesteld met stemmen die ten tijde van de vergadering worden uitgebracht. Dit wordt bij de oproeping vermeld.

In aanvulling op artikel 228 lid 1 kan het bestuur bepalen dat het stemrecht slechts kan worden uitgeoefend langs elektronische weg. Dit wordt bij de oproeping of bij de wijziging van de wijze van vergaderen vermeld.

In afwijking van artikel 248 lid 2 wordt een verzuim van de verplichting uit artikel 394 tot open394 , heeft het zijn taak onbehoorlijk vervuld vervulling een belangrijke oorzaak is van het noot is van een vennootschap onder firma of daan is aan de verplichtingen uit artikel 15i

baarmaking van de jaarrekening die betrekking heeft op het meest recente afgesloten boekjaar niet in aanmerking genomen, indien dat te wijten is aan de gevolgen van de uitbraak van COVID-19.
De rechtspersoon is verplicht tot openbaarmaking van de jaarrekening binnen acht dagen na de vaststelling. De openbaarmaking geschiedt door deponering van de vol- 


\section{Maandblad}

Ondernemingsrecht

Tabel $1 \quad$ (Vervolg)

\begin{tabular}{|c|c|c|}
\hline $\begin{array}{l}\text { Artikel } \\
\text { Nood- } \\
\text { wet }\end{array}$ & $\begin{array}{l}\text { Betreffen- } \\
\text { de rechts- } \\
\text { persoon }\end{array}$ & $\begin{array}{l}\text { Relevante } \\
\text { wettelijke } \\
\text { bepaling }\end{array}$ \\
\hline
\end{tabular}

Tekst wettelijke bepaling

ledig in de Nederlandse taal gestelde jaarrekening of, als die niet is vervaardigd, de jaarrekening in het Frans, Duits of Engels, bij het handelsregister, indien van toepassing op de wijze als voorgeschreven bij of krachtens artikel 19a van de Handelsregisterwet 2007. De dag van vaststelling moet zijn vermeld.

Art. 2:394 lid Is de jaarrekening niet binnen twee maan$2 \mathrm{BW}$ den na afloop van de voor het opmaken voorgeschreven termijn overeenkomstig de wettelijke voorschriften vastgesteld, dan maakt het bestuur onverwijld de opgemaakte jaarrekening op de in lid 1 voorgeschreven wijze openbaar; op de jaarrekening wordt vermeld dat zij nog niet is vastgesteld. Binnen twee maanden na gerechtelijke vernietiging van een jaarrekening moet de rechtspersoon een afschrift van de in de uitspraak opgenomen bevelen met betrekking tot de jaarrekening deponeren bij het handelsregister, met vermelding van de uitspraak.

Art. 2:394 lid Uiterlijk twaalf maanden na afloop van het $3 \mathrm{BW}$ boekjaar moet de rechtspersoon de jaarrekening op de in lid 1 voorgeschreven wijze openbaar hebben gemaakt.

Art. 2:300 lid $1 \mathrm{BW}$
Jaarlijks binnen zes maanden na afloop van het boekjaar van een stichting als bedoeld in artikel 360 lid 3, behoudens verlenging van deze termijn met ten hoogste vier maanden door het in lid 3 bedoelde orgaan op grond van bijzondere omstandigheden, maakt het bestuur een jaarrekening op en legt het deze voor hen die deel uitmaken van het in lid 3 bedoelde orgaan ter inzage ten kantore van de stichting. Binnen deze termijn legt het bestuur ook de krachtens artikel 392 lid 1 toe te voegen gegevens ter inzage voor hen die deel uitmaken van het in lid 3 bedoelde orgaan en het bestuursverslag, tenzij artikel 396 lid 7 voor zover het betreft het bestuursverslag, of artikel 403 voor de stichting gelden. $\mathrm{Zij}$ die deel uitmaken van het in lid 3 bedoelde orgaan kunnen kosteloos een afschrift van deze stukken verkrijgen.

\section{Bepaling Noodwet}

1. In afwijking van artikel 300 lid 1 kan de termijn van zes maanden na afloop van het boekjaar door het bestuur worden verlengd met ten hoogste vier maanden. In dat geval heeft het volgens de statuten bevoegde orgaan, voor zover dat een ander orgaan dan het bestuur is, geen bevoegdheid tot verlenging. 


\section{Maandblad}

Ondernemingsrecht

\section{Tabel $1 \quad$ (Vervolg)}

\begin{tabular}{llll}
\hline $\begin{array}{l}\text { Artikel } \\
\text { Nood- } \\
\text { wet }\end{array}$ & $\begin{array}{l}\text { Betreffen- } \\
\text { de rechts- } \\
\text { persoon }\end{array}$ & $\begin{array}{l}\text { Relevante } \\
\text { wettelijke } \\
\text { bepaling }\end{array}$ & Tekst wettelijke bepaling \\
\hline & Art. 2:300 lid & $\begin{array}{l}\text { De jaarrekening wordt uiterlijk een maand } \\
\text { na afloop van de termijn vastgesteld door } \\
\text { het daartoe volgens de statuten bevoegde } \\
\text { orgaan. Indien de statuten deze bevoegdheid } \\
\text { niet aan enig orgaan verlenen, komt deze } \\
\text { bevoegdheid toe aan het toezicht houdende } \\
\text { orgaan en bij gebreke daarvan an het } \\
\text { bestuur. }\end{array}$
\end{tabular}

Art. 29 lid 1 Ten aanzien van rechtspersonen die op het Overgangswet tijdstip van in werking treden van Boek 2 nieuw Burger- (Rechtspersonen) van het Burgerlijk Wetlijk Wetboek boek bestaan, zijn, voor zover niet anders is bepaald, dit boek en de bij de hoofdstukken 2-4 van de Invoeringswet Boek 2 nieuw B.W. vastgestelde bepalingen van toepassing op feiten die na dat tijdstip voorvallen.

Art. 74 Over- 1. Het van toepassing worden van de wet gangswet heeft geen gevolg voor de bevoegdheid nieuw Burger- $\quad$ van de rechter voor wie voordien een lijk Wetboek geding is aangevangen, noch voor de aard van dat geding en voor de rechtsmiddelen tegen de uitspraak.

2. In gedingen als bedoeld in lid 1 bepaalt de rechter op verzoek van een der partijen of ambtshalve een termijn waarbinnen partijen de gelegenheid wordt geboden hun stellingen en conclusies voor zover nodig aan te passen aan de wet of aan deze of een der volgende titels. Stelt de rechter partijen tot een zodanige aanpassing in de gelegenheid, dan staat tegen die beslissing geen rechtsmiddel open; wijst de rechter een daartoe strekkend verzoek af, dan staat een rechtsmiddel daartegen slechts gelijktijdig met de einduitspraak open.

3. Het tevoren geldende recht blijft van toepassing, indien een geding als bedoeld in lid 1 , in hoogste feitelijke instantie in staat van wijzen verkeert op het tijdstip waarop de wet van toepassing wordt, tenzij de rechter tot voortzetting van het geding beslist.

4. In een geding ter zake van een cassatieberoep tegen een, vóór het van toepassing worden van de wet tot stand gekomen, uitspraak blijft het voordien gel-

\section{Bepaling Noodwet}

2. In aanvulling op artikel 300 is artikel 6 van deze wet, alsmede artikel 38 lid 7, van overeenkomstige toepassing op een vergadering van het orgaan, bedoeld in artikel 300 lid 3 .

De artikelen 29, eerste lid, 74, 79, 80 en 81 van de Overgangswet nieuw Burgerlijk Wetboek zijn van overeenkomstige toepassing. 


\section{Maandblad}

Ondernemingsrecht

Tabel $1 \quad$ (Vervolg)

\begin{tabular}{|c|c|c|}
\hline $\begin{array}{l}\text { Artikel } \\
\text { Nood- } \\
\text { wet }\end{array}$ & $\begin{array}{l}\text { Betreffen- } \\
\text { de rechts- } \\
\text { persoon }\end{array}$ & $\begin{array}{l}\text { Relevante } \\
\text { wettelijke } \\
\text { bepaling }\end{array}$ \\
\hline
\end{tabular}

Tekst wettelijke bepaling

Bepaling Noodwet
dende recht van toepasing. Dit geldt mede voor de verdere behandeling van de zaak door het recht waarnaar na cas- satie is verwezen, tenzij de zaak als gevolg van de cassatie door dat gerecht in haar geheel opnieuw moet worden behandeld.

Art. 79 Over- Tenzij anders is bepaald, wordt een rechtsgangswet handeling die is verricht voordat de wet nieuw Burger- daarop van toepassing wordt, niet nietig of lijk Wetboek vernietigbaar ten gevolge van een omstandigheid die de wet, in tegenstelling tot het tevoren geldende recht, aanmerkt als een grond van nietigheid of vernietigbaarheid.

Art. 80 Over- 1. Een rechtshandeling die vernietigbaar gangswet was tot aan het tijdstip waarop de wet op nieuw Burger- haar van toepassing wordt, kan van dat lijk Wetboek tijdstip af niet langer worden vernietigd op grond van het gebrek dat haar tevoren aankleefde, indien de wet een zodanig gebrek niet aanmerkt als een grond van vernietigbaarheid.

2. Een rechtshandeling als bedoeld in lid 1, wordt op het daar genoemde tijdstip met terugwerkende kracht nietig, indien de wet een rechtshandeling met hetzelfde gebrek als nietig aanmerkt.

Art. 81 Over- 1. Een nietige rechtshandeling wordt op gangswet nieuw Burgerlijk Wetboek het tijdstip waarop de wet op haar van toepassing wordt, met terugwerkende kracht tot een onaantastbare bekrachtigd, indien zij heeft voldaan aan de vereisten die de wet voor een zodanige rechtshandeling stelt.

2. Een tevoren nietige rechtshandeling geldt van dat tijdstip af als vernietigbaar, indien de wet het gebrek dat haar aankleeft, als grond van vernietigbaarheid aanmerkt. Artikel 73a lid 1 is alsdan niet van toepassing indien het tevoren geldende recht een beroep op de nietigheid niet aan een bepaalde termijn bond.

3. De vorige leden gelden slechts, indien alle onmiddellijk belanghebbenden die zich op de nietigheid hadden kunnen beroepen, de handeling voordien als geldig hebben aangemerkt. Inmiddels 


\section{Maandblad}

Ondernemingsrecht

\section{Tabel $1 \quad$ (Vervolg)}

\begin{tabular}{lll}
\hline Artikel & Betreffen- & Relevante \\
Nood- & de rechts- & wettelijke \\
wet & persoon & bepaling
\end{tabular}

35

$35 \quad$ N.v.t. $\quad$ N.v.t. $\quad$ N.v.

$35 \quad$ N.v.t. $\quad$ N.v.t. $\quad$ N.v.t.
Bepaling Noodwet

verkregen rechten van derden behoeven aan bekrachtiging niet in de weg te staan, mits zij worden geëerbiedigd.

Tekst wettelijke bepaling

$\begin{array}{ll} & \text { verkregen rechten van derden behoeven } \\ & \text { aan bekrachtiging niet in de weg te } \\ & \text { staan, mits zij worden geëerbiedigd. }\end{array}$

2. In het koninklijk besluit kan worden bepaald dat paragrafen, artikelen of onderdelen van deze wet, met uitzondering van de paragrafen $1,6,10$ en 11 alsmede de artikelen 15 en 22, terugwerken tot en met 16 maart 2020.

3. Deze wet vervalt op 1 september 2020. Het tijdstip waarop deze wet vervalt kan bij koninklijk besluit worden bepaald op een ander tijdstip, met dien verstande dat dit tijdstip steeds ten hoogste twee maanden na het tijdstip ligt waarop de wet zou vervallen. (...)

6. In afwijking van het derde lid: a. vervallen de artikelen 15 en 22 op 1 september 2023;

(...) 